\title{
HUBUNGAN BEBAN KERJA DENGAN STRES KERJA PADA PERAWAT DI RUMAH SAKIT RAFLESIA KOTA BENGKULU
}

\author{
Septi Andrianti ${ }^{1}$ Ikhsan $^{2}$ Nurlaili $^{2}$ Sardaniah $^{2}$ \\ Program Studi Keperawatan STIKes Bhakti Husada Bengkulu ${ }^{1}$ \\ Program Studi Keperawatan FMIPA Univeritas Bengkulu ${ }^{2}$ \\ Email : andriantisepti@gmail.com
}

\begin{abstract}
ABSTRAK
Tenaga keperawatan yang melayani di pelayanan rawat inap cenderung memiliki beban kerja yang lebih banyak dibandingkan ruangan lainnya. Setiap hari, dalam melaksanakan pengabdiannya seorang perawat tidak hanya berhubungan dengan pasien, tetapi juga dengan keluarga pasien, teman pasien, rekan kerja sesama perawat, berhubungan dengan dokter dan peraturan yang ada di tempat kerja serta beban kerja yang terkadang dinilai tidak sesuai dengan kondisi fisik, psikis dan emosional. Tugas yang harus dilakukan perawat seperti melakukan asuhan keperawatan, pencatatan laporan asuhan keperawatan, observasi pasien, menerima pasien baru atau rujukan pasien ke rumah sakit lain. Masalah penelitian masih adanya perawat yang mengalami stress kerja di Rumah Sakit Raflesia. Tujuan penelitian diketahuiya hubungan beban kerja dengan stress kerja pada perawat di Rumah Sakit Raflesia Kota Bengkulu.

Jenis penelitian yang digunakan pada penelitian ini adalah survey analitik dengan rancangan cross sectional total populasi yaitu seluruh populasi dijadikan sampel dalam penelitian ini yang artinya jumlah sampel sebanyak 85 . Data dianalisis secara univariat dan bivariate dengan uji chi-square

Hasil penelitian menunjukkan sebagian besar $(58,8 \%)$ dengan beban kerja tingkat sedang dan sebagian besar $(51,8 \%)$ responden dengan tingkat stress rendah dengan nilai p 0,001 .

Simpulan terdapat hubungan beban kerja dengan tingkat stress kerja pada perawat di Rumah Sakit Raflesia Tahun 2018

Kata kunci : Beban Kerja, Stress Kerja Pada Perawat

\section{WORK LOAD RELATIONSHIP WITH WORK STRESS ON NURSES IN RAFLESIA HOSPITAL BENGKULU CITY}

\begin{abstract}
Nursing personnel who serve in inpatient services tend to have more workloads than other rooms. Every day, in carrying out his service a nurse not only deals with patients, but also with the patient's family, friends, colleagues, nurses, contact with doctors and regulations in the workplace as well as workloads which are sometimes considered not in accordance with physical conditions. Psychological and emotional preliminary. Tasks that must be performed by nurses such as nursing care, recording nursing care reports, observing patients, accepting new patients or referring patients to other hospitals. The research problem is there are still nurses who experience work stress at Raflesia Hospital. The purpose of the study was to find out the relationship between workload and work stress on nurses at the Bengkulu City Raflesia Hospital.

The type of research used in this study was an analytic survey with a total population cross sectional design, that is the entire population sampled in this study, which means 85 samples were analyzed. Data were analyzed univariate and bivariate by chi-square test.

The results showed most (58.8\%) with a moderate level of workload and most (51.8\%) respondents with low stress levels with a $p$ value of 0.001 .

Conclusion there is a relationship between workload and stress level of work for nurses at Raflesia Hospital in 2018
\end{abstract}

Keywords: Workload, Job Stress in Nurses 


\section{Pendahuluan}

Rumah sakit merupakan salah satu tempat kerja yang berpotensi menimbulkan bahaya. Rumah sakit di Amerika Serikat mencatat rata-rata 6,8 cedera atau kecelakaan yang berhubungan dengan pekerjaan dan penyakit untuk setiap 100 karyawan penuh pada tahun 2011, hal ini hampir dua kali lipat untuk industri swasta secara keseluruhan (OSHA, 2013).

Data survei Self-reported Workrelated Illness (SWI) dalam European Agency For Safety an Health at Work (2014) pada tahun 2011 menunjukkan bahwa perawat memiliki prevalensi stres tinggi yang berhubungan dengan pekerjaan. The Daily (2007) menemukan bahwa dua pertiga, atau $67 \%$ dari kepala perawat dan supervisor perawat dilaporkan mengalami stres kerja yang tinggi dari pekerjaan pelayanan kesehatan. American National Association for Occupational (2010) menempatkan kejadian stres kerja pada perawat berada diurutan paling atas pada empat puluh pertama kasus stres kerja. Tingginya angka kejadian stres kerja pada perawat juga terlihat di Indonesia.

Hasil survei yang dilakukan oleh PPNI (2010) sekitar 50,9\% perawat yang bekerja di empat provinsi di Indonesia mengalami stres kerja yaitu sering pusing, lelah, tidak bisa beristirahat karena beban kerja tinggi dan menyita waktu. Stres kerja juga merupakan penentu penting timbulnya depresi, penyebab keempat terbesar timbulnya penyakit di seluruh dunia.

Tenaga keperawatan adalah salah satu tenaga kesehatan yang juga ikut dalam melaksanakan penanganan terhadap pasien yang ada di rumah sakit. Tenaga keperawatan merupakan the caring profession yang memiliki peranan penting dalam menghasilkan kualitas pelayanan kesehatan di rumah sakit. Pelayanan yang diberikan berdasarkan pendekatan bio-psikososial-spiritual

Kesehatan RI , 2001).

Tenaga keperawatan yang melayani di pelayanan rawat inap cenderung memiliki beban kerja yang lebih banyak dibandingkan ruangan lainnya. Setiap hari, dalam melaksanakan pengabdiannya seorang perawat tidak hanya berhubungan dengan pasien, tetapi juga dengan keluarga pasien, teman pasien, rekan kerja sesama perawat, berhubungan dengan dokter dan peraturan yang ada di tempat kerja serta beban kerja yang terkadang dinilai tidak sesuai dengan kondisi fisik, psikis dan emosionalnya (Almasitoh, 2011).

Kondisi dan beban kerja di rawat inap perlu diketahui agar dapat ditentukan kebutuhan kuantitas dan kualitas tenaga perawat yang diperlukan dalam ruang sehingga tidak terjadi beban kerja yang tidak sesuai yang akhirnya menyebabkan stres kerja. Bila banyaknya tugas tidak sebanding dengan kemampuan baik fisik maupun keahlian dan waktu yang tersedia maka akan menjadi sumber stres (Ilyas, 2000)

Kondisi kerja memperlihatkan kontribusi paling besar terhadap terjadinya stres kerja kemudian tipe kepribadian dan beban kerja. Beban kerja yang berlebihan ini sangat berpengaruh terhadap produktifitas tenaga kesehatan dan tentu saja berpengaruh terhadap produktifitas perawat. Perawat merasakan bahwa 
jumlah perawat yang ada tidak sebanding dengan jumlah pekerjaan yang harus diselesaikan (Supardi, 2007).

Stres merupakan ketegangan yang disebabkan oleh fisik, emosi, sosial, ekonomi, pekerjaan atau keadaan, peristiwa serta pengalaman yang sulit untuk bertahan (Nasir dan Muhith, 2011). Stres yang terlalu banyak membuat kinerja seseorang menurun dan cenderung tidak produktif, tetapi stres yang sedikit akan membantu seseorang memusatkan perhatian dan kinerja seseorang (Noordiansah, 2010). Stres merupakan respon tubuh yang bersifat tidak spesifik terhadap setiap tuntutan atau beban atasnya. Stres dapat muncul apabila seseorang mengalami beban atau tugas berat dan orang tersbut tidak dapat mengatasi tugas yang dibebankan itu, maka tubuh akan berespon dengan tidak mampu terhadap tugas tersebut, sehingga orang tersebut dapat mengalami stres (Hidayat, 2011)

Seseorang yang mengalami stres mempunyai perilaku mudah marah, murung, gelisah, cemas dan semangat kerja yang rendah. Sehingga, ketika seorang perawat terkena stres maka kinerja dalam memberikan pelayanan keperawatan akan menurun, pada akhirnya akan mendatangkan keluhan dari pasien (Nurmalasari, 2012). Sedangkan Levin (2013) menyatakan bahwa manifestasi dari stres kerja perawat antara lain akibat karakterisasi pasien, pengkajian terhadap pasien, dan aspek lingkungan kerja yang mengganggu
Apabila stres mencapai titik puncak yang kira-kira sesuai dengan kemampuan maksimum kinerja karyawan maka pada titik ini stres tambahan cenderung tidak menghasilkan perbaikan kinerja selanjutnya bila stres yang di alami karyawan terlalu besar, maka kinerja akan mulai menurun, karena stres tersebut mengganggu pelaksanaan kerja karyawan dan akan kehilangan kemampuan untuk mengendalikannya atau menjadi tidak mampu untuk mengambil keputusan dan perilakunya menjadi tidak menentu. Akibat yang paling ekstrim adalah kinerja menjadi nol, karyawan mengalami gangguan, menjadi sakit, dan tidak kuat lagi untuk bekerja, menjadi putus asa, keluar atau menolak bekerja (Munandar, 2008)

Rumah Sakit Raflesia merupakan salah satu rumah sakit sebagai pelayanan tingkat pertama dan menerima pasien pengguna kartu Badan Penyelengara Jaminan Sosial (BPJS) sehingga jumlah kunjungan di rumah sakit raflesia meningkat. Fasilitas yang ada diantaranya, ruang rawat penyakit dalam, ruang rawat bedah, Instalasi Diklat dan Litbang, Instalasi Farmasi, Instalasi Gizi, Instalasi Rawat Darurat, Instalasi Laboratorium, Instalasi Laundry dan CSSD, Instalasi Pemeliharaan Sarana RS dan Sanitasi, Instalasi Radiologi, Instalasi Rawat Jalan (IRJA), Instalasi Rekam Medik dengan total sumber daya manusia yang ada 257 orang dengan rincian dokter umum sebanyak 24, dokter spesialis 21, 85 perawat, 12 ahli gizi dan tenaga laboratorium 8 orang dan bidan 7 orang. Adapun 
waktu kerja di Rumah Sakit Raflesia terbagi 3 yaitu shif pagi dari pukul $07.30-14.00$, shift sore dari pukul 13.00 - 20.00 dan shift malam dari pukul $19.30-08.00$.

Dalam kurun tiga tahun dari tahun 2015 sampai 2017 jumlah pasien yang berkunjung di Rumah Sakit Raflesia mengalami penurunan, yaitu pada tahun 2015 sebanyak 42.040 pasien, 2016 sebanyak 40.648 pasien, dan tahun 2017 sebanyak 38.393 pasien. Meskipun mengalami penurunan jumlah pasien namun tidak berarti beban kerja perawat RS. Raflesia menurun, karena rata-rata pasien yang berkunjung setiap harinya sebanyak 107 pasien. Apabila membandingkan antara jumlah perawat dan pasien dalam satu hari maka satu perawat dapat menangani 34 pasien (RS. Raflesia, 2017).

Penelitian yang dilakukan oleh Wibowo (2012) menunjukkan bahwa beban kerja berpengaruh positif terhadap stres kerja. Adanya pengaruh tersebut dikarenakan beban kerja sebagai perawat yang dirasakan oleh perawat terasa membebani yang pada akhirnya berdampak pada munculnya stres kerja. Hal tersebut sejalan dengan hasil penelitian yang dilakukan Nurmalasari (2012) yaitu beban kerja berpengaruh positif dan signifikan terhadap stres kerja.

Berdasarkan survei pendahuluan yang dilakukan pada bulan Januari 2018 didapat data jumlah seluruh perawat di Rumah Sakit Raflesia yaitu 85 orang dengan rincian 17 orang ruangan Seruni, 18 orang di Melati, 18 orang di ruangan angrek, 18 diruangan IGD, 6 orang di Kamar Operasi, 8 orang di ruang kebidanan dengan pembagian shift kerja menjadi 3 kelompok yaitu shift pagi jam 07.3014.00 WIB, shift sore jam 14.00-20.00 WIB, dan shift malam jam 20.00-07.30 WIB.Tugas yang harus dilakukan perawat seperti melakukan asuhan keperawatan, pencatatan laporan asuhan keperawatan, observasi pasien, menerima pasien baru atau rujukan pasien ke rumah sakit lain.

Hasil pra penelitian dengan cara wawancara kepada 5 orang perawat yang sedang dinas terdapat 4 orang merasakan beban yang paling berat yaitu pada shift malam karena mengantuk, merasa repot jika ada rujukan pasien ke rumah sakit lain, harus meninggalkan keluarga serta waktu untuk beristirahat berkurang. Keluhan lain yang dirasakan seperti lingkungan kerja yang kurang nyaman, merasa bosan, manajemen yang kurang baik dan kurangnya perhatian dari atasan.

Berdasarkan uraian diatas pekerjaan yang menumpuk, deadline dan tekanan kerja merupakan salah satu penyebab terjadinya stres pada pekerja sehingga dampak stres tersebut dapat menyebabkan kelelahan, kecemasan, panik, berkeringat dan tremor. Hal ini dapat menyebabkan gangguan tubuh untuk rileks, gangguan nafsu makan, pola tidur yang terganggu, perasaan tertekan dan stres juga dapat meningkatkan seseorang rentan untuk terkena gangguan mental, penyakit jantung dan beberapa gangguan lain-lainnya.

Berdasarkan hal tersebut maka stres pada perawat sangat perlu diperhatikan, karena apabila seorang 
perawat mengalami stres yang tinggi akan berdampak pada kualitas pelayanannya. Pada dasarnya perawat dituntut untuk mampu memberikan pelayanan secara teratur dan tepat waktu yang harus didukung oleh sikap ramah tamah, sopan santun dan mau bersabar serta mau menyisihkan waktunya untuk mendengarkan keluhan pasien dengan memberikan informasi yang jelas dan mudah dimengerti.

Berdasarkan penjelasan diatas sehingga peneliti untuk melakukan penelitian dengan judu hubungan beban kerja dengan stress kerja pada perawat di Rumah Sakit Raflesia Kota Bengkulu.

\section{Metode Penelitian}

Jenis penelitian yang digunakan pada penelitian ini adalah survey analitik dengan rancangan cross sectional, dimana variable independen (beban kerja) dan variable dependen (stress kerja) diukur dan dikumpulkan secara simultan atau dalam waktu yang bersamaan (Notoatmodjo, 2010). Populasi penelitian ini adalah seluruh perawat yang dinas di rumah Sakit Raflesia dengan jumlah sebanyak 85 orang.

Sampel adalah bagian dari populasi terjangkau yang dapat dipergunakan sebagai subjek penelitian melalui sampling (Notoatmodjo, 2010). Sedangkan sampling adalah proses menyeleksi porsi dari populasi yang dapat mewakili populasi yang ada. Dalam penelitian ini sample yang diambil menggunakan teknik total populasi yaitu seluruh populasi dijadikan sampel dalam penelitian ini yang artinya jumlah sampel sebanyak 85 orang dengan kiteria inklusi

a. Perawat yang tidak cuti

b. Bersedia jadi responden

c. Perawat yang dinas di ruangan rawat inap

Kriteria Ekslusi:

a. Perawat yang cuti

b. Tidak bersedia menjadi responden

c. Perawat di poli rawat jalan

Jenis Data

Kuesioner 1 memuat data demografi responden. Pernyataan pada kuesioner diberikan sebagai berikut :

a. Nama (inisial) :

b. Jenis kelamin : Laki-laki (diberi kode 1), perempuan (diberi kode 0)

c. Masa bekerja : 1 tahun atau kurang 1 tahun (diberi kode 0), lebih 1 tahun -5 tahun (diberi kode 1) dan lebih dari 5 tahun (diberikan kode 2)

d. Status Perkawian : Kawin ( diberikan kode 0) dan belum kawin (diberikan kode 1).

Kuesioner 2 merupakan kuesioner beban kerja dengan jumlah pertanyaan sebanyak 8 item pertanyaan. : $1=$ sangat tidak setuju, $2=$ tidak setuju, 3 = tidak tahu, $4=$ Setuju dan $5=$ sangat setuju. Kemudian dari tiap-tiap item pertanyaan dijumlahkan dengan nilai dikatakan berat jika skor 56-80\% (diberikan kode 0), sedang jika skor $31-55 \%$ (diberikan kode 1), dan ringan jika skor $<30 \%$ (diberikan kode 2 ).

Kuesioner 3 : data stress kerja adalah dengan menggunakan kuisioner OSI-R (Occupational Stress Inventory Resived Edition) Oleh (Osipow dan 
Spokane (1998) yang telah dimodifikasi penggunaannya dan telah diuji pertanyaan yang diajukan untuk menggukur stress sebanyak 30 pertanyaan dengan pilihan skor $1-5$. Nilai terendah pada penelitian ini adalah 30 dan tertinggi 150 dengan kriteria $1=$ tidak pernah , $2=$ jika menurut anda jarang, $3=$ jika menurut anda sering, $4=$ jika menurut anda hampir selalu, $5=$ jika menurut anda selalu. Hasil penelitian dikelompokan menjadi 2 yaitu stress tingkat sedang (bila skore 79 - 117) dan diberikan kode 0 , stress tingkat rendah (bila skore $30-78$ ) dan diberikan kode 1

Analisis bivariat dilakukan untuk mengetahui hubungan antara kedua variabel. Uji yang digunakan adalah uji beda rata-rata untuk sampel yang berhubungan (Paired $t$ test), yaitu uji yang menggunakan asumsi-asumsi data berdistribusi normal, dengan varians homogen dan diambil dari sampel yang acak. Analisa bivariat adalah analisa yang digunakan untuk melihat hubungan beban kerja perawat dengan stress kerja di Rumah Sakit Raflesia Kota Bengkulu dengan menggunakan uji statistic menggunakan rumus Chi-Square $\left(\mathrm{X}^{2}\right)$

\section{Hasil Penelitian dan pembahasan}

\section{Analisis Univariat}

Analisis univariat digunakan untuk melihat gambaran distribusi frekuensi dan karakteristik masing-masing variable meliputi usia, jenis kelamin, masa kerja, beban kerja dan stress kerja. Adapun hasil penelitian dapat dilihat pada tabel dibawah ini ;

Distribusi Karakteristik Responden Tabel 1 : Distribusi Frekuensi Distribusi Karakteristik Responden di Rumah Sakit Raflesia Tahun 2018

\begin{tabular}{lcc}
\hline $\begin{array}{l}\text { Karakteristik } \\
\text { Responden }\end{array}$ & F & \% \\
\hline $\begin{array}{l}\text { Lama Kerja } \\
\quad \leq 1 \text { tahun }\end{array}$ & 26 & 30,6 \\
$\quad 1-5$ Tahun & 35 & 41,2 \\
$\quad$ > Tahun & 24 & 28,2 \\
Jenis Kelamin & & \\
$\quad$ Perempuan & 43 & 50,6 \\
$\quad$ Laki - Laki & 42 & 49,4 \\
$\quad$ Status & & \\
Perkawinan & 34 & 40,0 \\
$\quad$ Kawin & 51 & 60,1 \\
$\quad$ Belum Kawin & & \\
\hline$\quad$ Jumlah & 85 & 100 \\
\hline
\end{tabular}

Tabel 1 diatas menunjukan bahwa hampir sebagian besar $(41,2 \%)$ responden dengan lama kerja 1-5 tahun, sebagian besar $(50,6 \%)$ responden berjenis kelamin perempuan, dan sebagian besar $(60,1 \%)$ responden dengan status perkawinan belum kawin.

Distribusi Beban Kerja Perawat Tabel 2 : Distribusi Frekuensi Distribusi Beban Kerja Perawat di Rumah Sakit Raflesia Tahun 2018

\begin{tabular}{ccc}
\hline Beban Kerja & Frekuensi & $\mathbf{\%}$ \\
\hline Berat & 20 & 23,5 \\
Sedang & 50 & 58,8 \\
Rendah & 15 & 17,6 \\
\hline Jumlah & 85 & 100 \\
\hline
\end{tabular}

Tabel 2 diatas menunjukan bahwa hampir sebagian $(23,5 \%)$ responden dengan beban kerja yang berat. 
Distribusi Stress Kerja Perawat

Tabel 3 : Distribusi Frekuensi Distribusi Stress Kerja Perawat di Rumah Sakit Raflesia Tahun 2018

\begin{tabular}{ccc}
\hline Stress Kerja & Frekuensi & $\mathbf{\%}$ \\
\hline Sedang & 41 & 48,2 \\
Rendah & 44 & 51,8 \\
\hline Jumlah & 85 & 100 \\
\hline
\end{tabular}

Tabel 3 diatas menunjukan bahwa hampir sebagian $(48,2 \%)$ responden memiliki stress kerja tingkat sedang.

\section{Analisis Bivariat}

Analisis bivariat bertujuan untuk mengetahui hubungan atau perbedaan pada variabel independen dan dependen. Pada penelitian ini analisis bivariat bertujuan untuk mengetahui hubungan beban kerja dengan tingkat stress kerja pada perawat.

\section{Tabel 4 : Hubungan Beban Kerja Dengan Tingkat Stress Kerja Pada Perawat di Rumah Sakit Raflesia} Tahun 2018 terdapat sebagian besar $(53,3 \%)$ dengan tingkat stress kerja sedang.

Hasil uji statistik dengan menggunakan uji chi-square didapatkan nilai $\mathrm{p}$ sebesar 0,012 (p value $<0,05$ ) artinya ada hubungan beban kerja dengan tingkat stress kerja pada perawat di Rumah Sakit Raflesia Tahun 2018

\section{Pembahasan}

\section{Beban Kerja Perawat}

Hasil penelitian didapatkan data bahwa sebagian besar $(58,8 \%)$ responden dengan beban kerja yang tingkat sedang. Berdasarkan hasil observasi dan wawancara diketahui bahwa beban kerja pada perawat di RS. Raflesia pada beberapa kegiatan antara lain mengantar pasien ke ruangan, pemasangan kateter intravena, melakukan heating pada luka, melakukan ganti balut serta melakukan dokumentasi asuhan keperawatan gawat darurat.

\begin{tabular}{|c|c|c|c|c|c|c|}
\hline \multirow{3}{*}{$\begin{array}{l}\text { Beban } \\
\text { Kerja }\end{array}$} & \multicolumn{4}{|c|}{ Stress Kerja } & \multirow{2}{*}{\multicolumn{2}{|c|}{$\begin{array}{l}\text { Total Beban kerja pada tingkat berat } \\
\text { sebanyak } 23 \% \text { terjadi pada perawat di }\end{array}$}} \\
\hline & \multicolumn{2}{|c|}{ Sedang } & \multicolumn{2}{|c|}{ Rendah } & & \\
\hline & $\mathrm{f}$ & $\%$ & $\mathrm{f}$ & $\%$ & $\mathrm{~N}$ & arena belur \\
\hline Berat & 15 & 75,0 & 5 & 25 & 20 & $\begin{array}{l}\text { tenaga khusus yang melakukan } \\
\text { lfiीdakam non keperawatan seperti }\end{array}$ \\
\hline Sedang & 18 & 36,0 & 32 & 64 & 50 & 100 mbersihkan ruangan seperti \\
\hline Rendah & 8 & 53,3 & 7 & 46,7 & 15 & 00 mereskan sampah habis pakai, \\
\hline Jumlah & 41 & 48,2 & 44 & 51,8 & 85 & $1 \mathrm{MQmbersihkan}$ instrumen medis, \\
\hline $\begin{array}{l}\text { Berda } \\
\text { bahwa d } \\
\text { beban ke } \\
\text { besar ( } 75 \\
\text { sedang, d } \\
\text { dengan b } \\
\text { sebagian } \\
\text { keria van }\end{array}$ & arka & $\begin{array}{l}\text { tabel } \\
\text { respc }\end{array}$ & & anjuka & & $\begin{array}{l}\text { jumlah tenaga non medis yang } \\
\text { bertugas mengantarkan pasien ke } \\
\text { ruangan juga masih terbatas } \\
\text { jumlahnya. Selain itu jumlah tenaga } \\
\text { perawat di masing - masing ruangan } \\
\text { belum berdistribusi sesuai dengan } \\
\text { jumlah beban kerja yang ada sehinga } \\
\text { masih belum seimbang dengan jumlah } \\
\text { kunjungan pasien yang ada. }\end{array}$ \\
\hline
\end{tabular}

dengan beban kerja yang rendah 
Berdasarkan hasil kuesioner didapatkan hasil bahwa $62,1 \%$ reponden menyatakan bahwa beratnya beban kerja yang dirasakan karena terlalu banyaknya tuntutan dari keluarga pasien. Tingginya tuntutan dari keluarga pasien kepad perawat membuat perawat atau responden merasa kurang nyaman dalam bekerja dan tidak dapat menjaga keselamatan pasien, hal ini dapat dilihat dari kuesioner bahwa $57,9 \%$ responden menyatakan kurang nyaman terhadap tuntutan keluarga pasien untuk keselamatan pasien. Hasil penelitian ini sesuai dengan hasil penelitian yang dilakukan oleh Haryanti (2013) mengatakan hampir $50 \%$ beban kerja perawat tinggi, dimana tugas perawat selain menerima dan mengantar pasien baru ke ruangan dan melakukan tindakan keperawatan, perawat juga melayani tuntutan dari keluarga pasien.

Selain itu terdapat $52,9 \%$ responden menyatakan bosan apabila harus mengerjakan observasi pasien setiap jam. Hal tersebut sebagaimana diungkapkan oleh Togia (2005) bahwa beban kerja yang tinggi dan tugas rutin yang berulang dapat menyebabkan kelelahan fisik, emosional dan mental.

Beratnya beban kerja pada penelitian diketahui rasio perawat yang tidak sesuai dengan jumlah pasien hal ini diketahui bahwa 53\% responden menyatakan sangat setuju jumlah pasien tidak sesuai dengan jumlah perawat yang ada. Hal ini didukung oleh penelitian Jauhari (2005) bahwa standar beban kerja perawat senantiasa harus sesuai dengan asuhan keperawatan yang berorientasi pada kebutuhan pasien. Untuk menghasilkan pelayanan yang efektif dan efisien harus diupayakan kesesuaian antara ketersediaan tenaga perawat dengan beban kerja yang ada.

Hasil penelitian ini sama dengan yang disampaikan oleh Hay dan Oken (1972) dalam Lloyd (2007) yang menyampaikan bahwa beban kerja perawat di ruang IGD tergolong berat. Beban kerja yang tergolong berat karena parawat dalam melakukan kegiatannya harus secara cermat, cepat dan tepat melakukan identifikasi setiap pasien yang datang karena dituntut dengan keberhasilan penyelamatan jiwa tergantung dari pelayanan yang di berikan di IGD. Dalam waktu yang bersamaan perawat harus selalu waspada terhadap kedatangan pasien gawat maupun darurat yang harus diselamatkan jiwanya.

Hasil penelitian juga didapatkan terdapat sebagian kecil perawat yang memiliki beban kerja rendah. Hal ini dapat terjadi karena pada saat dinas selama 6 hari tidak banyak terdapat kunjungan pasien, penanganan pasien juga dilakukan secara bersama-sama sehingga secara singkat waktu penyelesaian tindakan yang dibutuhkan sedikit.

Suma'mur (2009), setiap beban kerja yang diterima oleh seseorang harus sesuai atau seimbang baik terhadap kemampuan fisik, kemampuan kognitif maupun keterbatasan manusia yang menerima beban tersebut. Beban kerja optimum harus dicapai bila ingin mendapatkan produktivitas yang tinggi, namun demikian jika beban pekerjaan terlalu rendah atau terlalu tinggi maka akan 
menyebabkan produktivitas yang rendah pula.

Beban kerja yang terlalu berlebih menimbulkan kelelahan baik fisik atau mental dan reaksi-reaksi emosional seperti sakit kepala, gangguan pencernaan, dan mudah marah. Sedangkan pada pekerjaan yang terlalu sedikit dimana pekerjaan yang terjadi kerena pengulangan gerak akan menimbulkan kebosanan dan rasa monoton. Kebosanan dalam kerja rutin sehari-hari karena tugas atau pekerjaan yang terlalu sedikit mengakibatkan kurangnya perhatian pada pekerjaan sehingga secara potensial membahayakan pekerja. Beban kerja yang berlebih atau rendah dapat menimbulkan stres kerja (Manuaba, 2000).

\section{Tingkat Stress Kerja}

Tabel 4 diatas menunjukan bahwa sebagian besar $(51,8 \%)$ responden memiliki stress kerja tingkat rendah dan 48,2\% mengalami stress tingkat sedang. Penelitian ini sesuai dengan penelitian yang dilakukan Simanjorang (2008) yang menyatakan bahwa perawat di RSU Dr Pring Medan mengalami stres kerja termasuk katagori sedang.

Tingginya persentase stres kerja sedang yang dialami perawat di ruang rawat inap dipengaruhi oleh beberapa faktor. Faktor pertama yaitu tidak seimbangnya jumlah rasio tenaga perawat dengan jumlah pasien. Seorang perawat di ruang rawat inap bertanggung jawab terhadap 12 pasien. Hal ini sesuai dengan pendapat Tutik (2012) yang menyatakan bahwa idealnya, pelayanan/ askep yang dilakukan oleh perawat profesional untuk sekelompok klien semenjak masuk RS sampai pulang adalah 2 (dua) 3 (tiga) perawat untuk 8 (delapan) 12 pasien.

Faktor kedua, sebagian besar pasien menderita penyakit infeksi yang dapat menyebabkan perawat merasa khawatir terjadinya infeksi nosokomial atau kemungkinan tertular. Faktor yang terakhir adalah shift work. Idealnya seorang pekerja bekerja selama 40 jam/minggu. Namun dengan adanya shift work, rata-rata perawat dapat bekerja selama 52 jam/minggu. Overload jam kerja akibat shift work pada perawat dapat menjadi salah satu pemicu terjadinya stres kerja.

Hasil ini sesuai dengan pendapat Grain (1999) yang mengatakan bahwa profesi perawat merupakan tenaga kesehatan yang paling tinggi interaksinya dengan pasien sehingga dalam melaksanakan tugasnya menghadapi banyak stressor. Kondisi tersebut diatas dapat berakibat terjadinya stres kerja pada perawat, yang pada akhirnya dapat menyebabkan tidak terlaksananya pekerjaan secara maksimal dalam mewujudkan visi dan misi rumah sakit. Selain itu bagi individu perawat, konsekuensi stres kerja yang berkelanjutan akan menyebabkan menurunnya produktivitas kerja.

Penelitian ini juga menunjukan bahwa stres kerja pada tingkat sedang lebih banyak dialami oleh perempuan. Penelitian ini sejalan dengan penelitian Gunawati (2006) yang mengemukakan bahwa secara 
umum wanita mengalami stres 30\% lebih tinggi daripada laki-laki. Hal ini disebabkan karena respon fisiologis yang berbeda antara laki-laki dan perempuan. Pada saat perempuan menghadapi stres, tubuh akan memberikan respon fisiologis berupa aktivitas dari beberapa hormone neurotransmitter di dalam otak. Lebih lanjut lagi perempuan lebih menderita stres daripada laki-laki disebabkan karena prolaktin perempuan lebih tinggi daripada lakilaki. Hormone ini memberikan umpan balik negatif pada otak sehingga dapat meningkatkan trauma emosional stres fisik (Crowin, 2007).

Faktor berikutnya pada penelitian ini jumlah responden perawat perempuan lebih banyak dibandingkan dengan responden perawat laki-laki, sehingga proporsi responden perawat laki-laki dan perawat perempuan tidak proporsional dan belum dapat menggambar perbedaan stres yang sesungguhnya. Penelitian lebih lanjut berdasar jenis kelamin dengan jumlah yang proporsional antara perawat laki-laki dan perempuan perlu dilakukan sehingga didapat hasil yang lebih tepat untuk tingkat stres kerja berdasarkan jenis kelamin.

Pada tingkat stress berdasarkan status perkawinan, penelitian menunjukan bahwa stres kerja pada tingkat sedang lebih banyak dialami oleh perawat yang sudah menikah. Penelitian ini sejalan den penelitian yang dilakukan oleh Vierdelina (2008) yang menyatakan bahwa stres kerja mayoritas terjadi pada responden yang sudah menikah $(55,8 \%)$ dibandingkan dengan responden yang belum menikah. Hal ini disebabkan karena permasalahan yang sering terjadi di keluarga, terutama karena sebagian besar responden merupakan keluarga muda yang masih memiliki anak balita. Kondisi keluarga yang membutuhkan perhatian khusus seperti pada saat anak atau pasangan sakit sementara harus tetap bekerja sehingga dapat menjadi stres tersendiri bagi perawat yang sudah berkeluarga. Hal ini didukung oleh Santrock (2003) yang menyatakan bahwa keluarga dapat menjadi salah satu faktor yang dapat menjadi pencetus terjadinya stres.

Penelitian ini pula menyebutkan bahwa pada tingkat stress kerja berdasarkan lama kerja menunjukan bahwa perawat dengan masa kerja kurang dari 1 tahun tahun mempunyai tingkat stres kerja yang paling tinggi yang disebabkan oleh beberapa factor. Faktor pertama yaitu tidak adanya training dan atau pelatihan kepada perawat baru, sehingga perawat baru harus beradaptasi sendiri dan belajar tanpa adanya bimbingan dari perawat lain. Faktor yang kedua yaitu perawat junior mempunyai beban kerja yang lebih tinggi akibat pendelegasian beban kerja dari perawat senior kepada perawat junior.

Stres kerja perawat dapat terjadi apabila perawat dalam bertugas mendapatkan beban kerja yang melebihi kemampuannya sehingga perawat tersebut tidak mampu memenuhi atau menyelesaikan tugasnya, maka perawat tersebut dikatakan mengalami stres kerja. Manifestasi dari stres kerja perawat 
antara lain akibat karakterisasi pasien, pengkajian terhadap pasien, dan aspek lingkungan kerja yang mengganggu merupakan langkah awal dalam menangani masalah-masalah yang datang mengenai tingkat kepadatan ruangan emergency, efisiensi pelaksanaan tugas, serta adanya tuntutan untuk menyelamatkan pasien (Levin et al, 2004).

Apabila stres mencapai titik puncak yang kira - kira sesuai dengan kemampuan maksimum kinerja karyawan maka pada titik ini stres tambahan cenderung tidak menghasilkan perbaikan kinerja selanjutnya bila stres yang dialami karyawan terlalu besar, maka kinerja akan mulai menurun, karena stres tersebut mengganggu pelaksanaan kerja karyawan dan akan kehilangan kemampuan untuk mengendalikannya atau menjadi tidak mampu untuk mengambil keputusan dan perilakunya menjadi tidak menentu. Akibat yang paling ekstrim adalah kinerja menjadi nol, karyawan $\mathrm{m}$ engalami gangguan, menjadi sakit, dan tidak kuat lagi untuk bekerja, menjadi putus asa, keluar atau menolak bekerja (Munandar, 2008).

\section{Hubungan Beban Kerja Dengan Stress Kerja \\ Berdasarkan tabel 5} menunjukan bahwa dari 20 responden dengan bebn kerja berat terdapat sebagian besar $(75 \%)$ dengan stress kerja yang sedang, dan dari 50 orang responden dengan beban kerja sedang terdapat sebagian besar (64\%) dengan stress kerja yang rendah serta dari 15 orang dengan beban kerja yang rendah terdapat sebagian besar $(53,3 \%)$ dengan tingkat stress kerja sedang.

Hasil uji statistik dengan menggunakan uji chi-square didapatkan nilai $\mathrm{p}$ sebesar 0,012 (p value $<0,05)$ artinya ada hubungan beban kerja dengan tingkat stress kerja pada perawat di Rumah Sakit Raflesia Tahun 2018. Menurut Everly dan Giordana (Munandar, 2001), beban kerja secara kuantitatif dan kualitatif merupakan kemungkinan sumber stres pekerjaan, yang termasuk juga beban kerja berlebih secara fisik maupun mental, yaitu harus terlalu banyak melakukan banyak hal. Perawat diruangan juga melaksanakan asuhan keperawatan selama 24 jam dan bekerja secara bergiliran / shift jaga. Shift jaga sering tidak seimbang dengan jumlah pasien akibatnya perawat sering bekerja melebihi kapasitasnya (PPNI, 2000).

Setiap orang memiliki kemampuan yang berbeda-beda dalam nenghadapi stres yang dihadapi. Menurut Siagian (2002) secara sosial budaya, pegawai wanita yang bermoral tinggi akan memiliki tugas tambahan. Berdasarkan pemikiran bahwa perawat perempuan akan lebih teliti, lebih sabar, lebih menghargai, lebih bertanggung jawab dalam menyelesaikan tugas, sehingga tidak jarang pimpinan akan memberikan tugas tambahan karena merasa yakin pasti akan diselesaikan dengan baik. Setiap orang pernah stres dan akan mengalaminya, akan tetapi kadarnya berbeda-beda serta dalam jangka waktu yang tidak sama (Hardjana, 2004). 
Suliswati (2005) menyatakan bahwa stres merupakan tanggapan menyeluruh dari tubuh baik fisik maupun mental terhadap setiap tuntutan ataupun perubahan yang mengganggu, mengancam rasa aman dan harga diri individu. Pengalaman stres adalah pengalaman pribadi dan bersifat subjektif. Stres terjadi apabila individu menilai situasi yang ada pada dirinya adalah situasi yang mengancam.

Hasil penelitian ini sesuai dengan hasil penelitian yang dilakukan oleh Mahwidhi (2010) tentang pengaruh beban kerja terhadap stres kerja pada perawat di RSU Dr.Soeroto Ngawi didapatkan hasil bahwa terdapat pengaruh beban kerja fisik (subyektif) dan beban kerja mental (subyektif) terhadap stres kerja dengan nilai probabilitas masing-masing sebesar 0,000 dan 0,043.Penelitian ini sejalan juga dengan penelitian Hay dan Oken (1972) dalam Lloyd (2007) juga menyampaikan bahwa beban kerja perawat di ruang IGD tergolong berat karena harus melakukan penanganan pada pasien yang datang dengan cepat dan tepat.

Bekerja di ruang rawat inap dalam setiap kesempatan akan menemui pasien yang memiliki karakteristik yang bervariasi yang berdampak pada kondisi dan beban kerja yang berbeda. Untuk itu perawat harus peran sebagai tenaga serba bisa, memiliki inisiatif, berperilaku kreatif serta memiliki wawasan yang luas dengan motivasi kerja keras, cerdas, iklas dan kerja berkualitas. Jenis pasien yang dirawat di ruangan rawat inap rumah sakit dapat dipandang sebagai tuntutan terhadap pelayanan kesehatan jika tidak dikelola dengan baik maka akan berakibat terjadinya stress kerja (Boenisch dkk, 2004).

Menurut Roy (1991) bahwa faktor beban kerja termasuk di dalam stimulus fokal dimana secara langsung berhadapan dengan seseorang dan responnya segera. Perawat yang merasa beban kerjanya tinggi akan langsung berespon untuk beradaptasi dengan kondisi yang ada. Berbagai keluhan fisik yang dirasakan merupakan respon kelelahan dari beratnya beban kerja.

Berdasarkan penelitian dari Rodrigues(2010) bahwa ada hubungan antara beban kerja dan tingkat stres perawat IGD, semakin tinggi beban kerja maka semakin tinggi juga tingkat stres perawat. Menurut Manuaba (2000), akibat beban kerja yang terlalu berat dapat mengakibatkan seorang pekerja menderita gangguan atau penyakit akibat kerja. Beban kerja yang terlalu berlebihan akan menimbulkan kelelahan baik fisik atau mental dan reaksi-reaksi emosional seperti sakit kepala, gangguan pencernaan dan mudah marah. Sedangkan pada beban kerja yang terlalu sedikit dimana pekerjaan yang terjadi karena pengulangan gerak akan menimbulkan kebosanan, rasa monoton. Kebosanan dalam kerja rutin sehari-hari karena tugas atau pekerjaan yang terlalu sedikit mengakibatkan kurangnya perhatian pada pekerjaan sehingga secara potensial membahayakan pekerja. Beban kerja yang berlebihan atau rendah dapat menimbulkan stress kerja 
Secara umum stres kerja dipengaruhi oleh banyak faktor selain beban kerja, seperti yang disebutkan dalam penelitian Restiaty, et al (2006) tentang beban kerja dan perasaan kelelahan menyimpulkan adanya hubungan beban kerja di tempat kerja dengan kelelahan kerja yang merupakan gejala fisik stress kerja, artinya semakin berat beban kerja di tempat kerja maka semakin tinggi tingkat stress kerja. Lebih lanjut dijelaskan bahwa variabel yang berhubungan dengan beban kerja adalah tempat bekerja, jenis pekerjaan, serta beban mental.

Banyaknya pekerjaan yang melebihi kapasitas menyebabkan kondisi fisik perawat mudah lelah dan mudah tegang. Pelayanan keperawatan juga sangat kompleks, dimana membutuhkan kemampuan secara teknis dan pengetahuan yang lebih. Beban pekerjaan yang begitu banyak pemenuhan kebutuhan, penanganan masalah dan pada akhirnya sangat menguras energi baik fisik ataupun kemampuan kognitif. Kondisi perawat yang stres dengan adanya beban pekerjaan yang sudah berat hendaknya tidak ditambah lagi dengan bebanbeban lain di luar tugas sebagai perawat. Sebagai contoh adalah beban bimbingan mahasiswa praktek, beban pengurus organisasi, atau beban lain yang pada akhirnya semakin memperberat, sehingga tingkat stres perawat semakin meningkat.

Beban kerja berlebih dapat menyebabkan stres. Penelitian tentang stres perawat IGD yang dilakukan di Malaysia oleh Lexshimi (2007), yang hasilnya menunjukkan bahwa $100 \%$ perawat yang menjadi responden mengatakan pernah mengalami stres selama bertugas di ruang IGD. Mereka mengalami keluhan sakit kepala, nyeri dada, nyeri perut, bahkan ada yang menyampaikan kehilangan libido. Dari responden didapatkan bahwa yang menyebabkan mereka stres diantaranya adalah: beban bekerja dengan alat canggih yang sangat menegangkan, adanya ketidaknyamanan bekerjasama dengan staf lain dan kurangnya pengalaman bekerja di ruang IGD.

Simpulan

Responden sebagian besar (23,5\%) dengan beban kerja tingkat berat di Rumah Sakit Raflesia Tahun 2018. Responden sebagian besar (48,2\%) responden dengan tingkat stress sedang di Rumah Sakit Raflesia. Terdapat hubungan beban kerja dengan tingkat stress kerja pada perawat di Rumah Sakit Raflesia Tahun 2018.

Manajemen stres yang efektif pengelolaan waktu, teknik relaksasi, pemecahan masalah yang kreatif . Perlu adanya kegiatan-kegiatan yang ditujukan untuk mengurangi tingkat stres kerja perawat. Rumah sakit perlu mengalokasi dana untuk biaya rekreasi ke tempat yang dapat mendistraksi perawat dari lingkungan kerja minimal 1 (satu) tahun sekali. Perlu adanya rotasi atau mutasi bagi perawat yang telah la bertugas di ruang perawatan rawat inap minimal sekali dalam (satu) tahun.Perlu adanya penambahan jumlah perawat di ruang rawat inap dengan beban kerja yang tinggi. 


\section{Daftar Pustaka}

Almasitoh, U. H. 2011. Stres Kerja Ditinjau dari Konflik Peran Ganda dan Dukungan Sosial pada Perawat.Psikoislamika Jurnal Psikologi Islam. Vol. 8 (1): 63-82

Depkes RI. 2001. Keputusan menteri kesehatan RI nomor: 836/MENKES/SK/VI/2005 tentang pedoman pengembangan manajemen kinerja perawat dan bidan. Jakarta. Depkes RI.

Hidayat, A. dan A. Alimul. 2011. Pengantar konsep dasar keperawatan. Edisi Kedua. Jakarta: Salemba Medika.

Ilyas, Y. 2000. Kinerja, teori, penilaian, dan penelitian. Jakarta. Pusat Kajian Ekonomi Kesehatan FKM Universitas Indonesia.

Levin, Zeller, J. M., \& Levin, P. F. 2013. Mindfulness Interventions to Reduce Stress Among Nursing Personel: An Occupational Health Perspective. Workplace Health and Safety, Vol. 61, No. 2

Munandar. 2008. Psikologi Industri dan Organisasi. Jakarta: Universitas Indonesia (UI-Press)

Nasir, A \& Muhith, A. 2011. Dasar Dasar Keperawatan Jiwa. Jakarta : Salemba. Medika.

Notoatmodjo, S. 2002. Metodologi Penelitian Kesehatan. Jakarta: Rineka Cipta.
Nurmalasari. 2012. Kontribusi Hardiness dan Self Eficacy Terhadap Stres Kerja (Studi pada perawat RSUP dr. Soeradji Tirtonegoro Klaten). Jurnal Psikologi. Halaman: 47-57

Noordiansah, Pasih. 2010. Pengaruh Lingkungan Kerja Terhadap Stres Kerja Perawat (Studi Pada. Rumah Sakit Muhammadiyah Jombang). Jurnal Ilmiah

OSHA. 2013. Exposure to Stress: Occupational Hazards in Hospitals. http://www.cdc.gov/niosh/docs/ PPNI. 2010. http://www.innappni.or.id.

Supardi M. 2007. Pengaruh Faktor Organisasional pada Stres Kerja para Perawat dengan Pengalaman Kerja Sebagai Variabel Pemoderasi.Jurnal Manajemen Bisnis Syariah. Vol. 2 (5): 955967 